\title{
Quantitative Assessment for Training of Senior Scientific Staff
}

\author{
V. A. Gurtov ${ }^{1}$, L. V. Shegoleva ${ }^{2}$ \\ Petrozavodsk State University \\ Petrozavodsk, Russian Federation \\ 1vgurt@psu.karelia.ru, ${ }^{2}$ schegoleva@petrsu.ru
}

\author{
G. I. Dmitriev \\ Saint Petersburg Electrotechnical University "LETI" \\ St. Petersburg, Russian Federation \\ sznmc@mail.ru
}

\begin{abstract}
The human society since ancient times has questions "Whom to teach?", "What to teach?", "How long to teach?". The answers to these questions are changing along with the structure of human society, the structure of the economy. Currently, the economy requires qualified staff with a good education, and progress requires new technological ideas, the generators of which are representatives of the scientific community. Staff training for the scientific community is a separate complex and spending task. An insufficient number of graduated scientific staff entails inhibition in innovative development, and an oversupply of such graduates is a waste of state money and causes problems for the career path of the graduates themselves.
\end{abstract}

Key words—senior scientific staff training; scientific degree; training staff planning; forecasting; labor flow

\section{INTRODUCTION}

The task of predicting the optimal number of scientific staff becomes relevant. The international scientific community concerns about the significant growth in the number of $\mathrm{PhD}$ graduate students [1]. In 2017, the European Science Foundation conducted a study of career paths of people who graduated with a $\mathrm{PhD}$ degree [2], in which took part about $23 \%$ of those who graduated with a degree in the last 6 years preceding the study. The survey showed that only a little more than a half of respondents work in the academic sector. Less than half of polled people work in non-academic sector and hold a position corresponding to their academic degree or at least a master's degree. The result of the study indicates a certain redundancy of trained specialists with academic degrees.

In Russia, from 2011 to 2018, 121 thousand of doctoral research scholars defended their thesis. Their average age is 32 years. At the same time, the number of researchers under the age of 40 reaches 23 thousand [3], and university workers 24 thousand [4]. It turns out that less than a quarter of $\mathrm{PhD}$ graduates work in science and education, where their academic degree is in demand first of all.

Thus, the process of forecasting the demand for senior scientific staff is necessary for planning the number of enrollment to graduate school and graduation from it with the defense of a thesis.

Forecasting the needs for candidates and doctors of sciences [5] is based on the calculation of the annual additional needs, for the assessment of which it is necessary to know the amount of natural retirement of staff.
Depending on the forecasting models used, two approaches are used to assess the natural staff retirement.

\section{NATURAL-AGE RETIREMENT DURING THE LABOR FLOW}

For dynamic models describing the labor flow, natural retirement includes two components: death during the performance of labor functions and retirement by age. To calculate the first component, one can use ageing factor obtained from official statistics on the annual age structure of the Russian population over the past 10 years (Table 1).

\section{TABLE I. AGEING FACTOR}

\begin{tabular}{|l|l|}
\hline \multicolumn{1}{|c|}{ Age } & Ageing factor \\
\hline before 25 & 1 \\
\hline $25-29$ & 1 \\
\hline $30-34$ & 0,999963 \\
\hline $35-39$ & 0,997889 \\
\hline $40-44$ & 0,988042 \\
\hline $45-49$ & 0,964374 \\
\hline $50-54$ & 0,925329 \\
\hline $55-59$ & 0,869745 \\
\hline $60-64$ & 0,795848 \\
\hline $65-69$ & 0,709277 \\
\hline $70-75$ & 0,579284 \\
\hline
\end{tabular}

Thus, among researchers up to 70 years old with a scientific degree of a candidate of science, up to 5 thousand people can leave up annually at working age, among researchers who have a scientific degree of a doctor of science - up to 2.7 thousand.

Candidates of science who have reached the age of 70 years and over reach a number of 10.8 thousand people, doctors of science -9.4 thousand [3], of them at the age of 70 years about 3.2 thousand candidates of science and 0.9 thousand doctors of science.

If we assume that reaching the age of 70 years is the reason for the retirement of the researcher worker, then annually the natural-age retirement of candidates of sciences will be about 8.5 thousand people, and doctors of sciences - about 3.6 thousand people.

We will carry out similar calculations for the higher education sector. The annual retirement, subjected to termination of employment at the age of 65 , is equal to 11.8 thousand for candidates of science, 3.7 thousand for doctors of science. 


\section{THE ROTATION COEFFICIENT}

The second approach is associated with the calculation of the rotation coefficient, which shows the share of annually retired personnel of the senior scientific staff (candidates of science and doctors of science) in relation to their total number in the current year and is equal to the inverse ratio of the average duration of work of these staff. For its calculation it is necessary to know the age of the beginning of labor activity, which coincides with the age of the thesis defense, and the age of retirement. If we assume that the age of the retirement for a candidate of science is 65 years, and for a doctor of science 70 years, then the rotation coefficients on average will be 0.031 and 0.043 .

It is important to know that for different branches of science and different sectors of the economy, these values differ significantly. Table 2 shows the average age of defense of a candidate thesis in the context of groups of scientific specialties and places of work of doctoral research scholars.

TABLE II. THE AVERAGE AGE OF DEFENSE OF A CANDIDATE THESIS

\begin{tabular}{|c|c|c|c|c|}
\hline Specialties & Universities & $\begin{array}{c}\text { Academy of } \\
\text { Sciences }\end{array}$ & $\begin{array}{c}\text { Other Research Institutes, } \\
\text { Industrial Enterprises }\end{array}$ & $\begin{array}{c}\text { Other } \\
\text { organizations }\end{array}$ \\
\hline 01.01.00 Mathematics & 30 & 28 & 28 & 29 \\
\hline 01.02.00 Mechanics & 30 & 30 & 31 & 31 \\
\hline 01.04.00 Physics & 30 & 31 & 32 & 31 \\
\hline 02.00.00 Chemistry & 29 & 28 & 30 & 30 \\
\hline 03.01.00 Physicochemical Biology & 30 & 29 & 31 & 32 \\
\hline 03.02.00 General biology & 31 & 32 & 33 & 34 \\
\hline 03.03.00 Physiology & 31 & 30 & 33 & 33 \\
\hline 05.01.00 Engineering geometry and computer graphics & 31 & & 34 & 31 \\
\hline 05.02.00 Mechanical engineering & 31 & 40 & 31 & 33 \\
\hline 05.04.00 Power, metallurgy and chemical engineering & 31 & 29 & 39 & 33 \\
\hline 05.05.00 Transport, mining and construction engineering & 31 & 29 & 30 & 34 \\
\hline 05.07.00 Aircraft, rocket and space technology & 30 & & 33 & 35 \\
\hline 05.08.00 Shipbuilding & 34 & 31 & 31 & 33 \\
\hline 05.09.00 Electrical Engineering & 31 & 28 & 31 & 32 \\
\hline $\begin{array}{l}\text { 05.11.00 Instrument-making, metrology and information-measuring } \\
\text { devices and systems }\end{array}$ & 29 & 33 & 34 & 32 \\
\hline 05.12.00 Radio engineering and communication & 30 & 31 & 32 & 32 \\
\hline 05.13.00 Computer Science, Computer Engineering and Control & 30 & 30 & 30 & 31 \\
\hline 05.14.00 Energetics & 30 & 32 & 33 & 32 \\
\hline 05.16.00 Metallurgy and materials science & 30 & 32 & 32 & 35 \\
\hline 05.17.00 Chemical Technology & 29 & 32 & 34 & 32 \\
\hline 05.18.00 Food Technology & 31 & 29 & 34 & 34 \\
\hline $\begin{array}{l}05.19 .00 \text { Technology of materials and products of textile and light } \\
\text { industry }\end{array}$ & 31 & & 29 & 35 \\
\hline 05.20.00 Processes and machines for agroengineering systems & 32 & 36 & 30 & 33 \\
\hline $\begin{array}{l}05.21 .00 \text { Technology, machinery and equipment for logging, forestry, } \\
\text { wood processing and chemical processing of wood biomass }\end{array}$ & 32 & 34 & 32 & 33 \\
\hline 05.22 .00 Transport & 31 & 32 & 39 & 35 \\
\hline 05.23.00 Sivil engineering and architecture & 31 & 31 & 33 & 32 \\
\hline 05.25.00 Documentary Information & 35 & 36 & 34 & 38 \\
\hline 05.26.00 Human Safety & 32 & 30 & 36 & 35 \\
\hline 05.27.00 Electronics & 29 & 31 & 34 & 32 \\
\hline 06.03.00 Forestry & 30 & 32 & 32 & 35 \\
\hline 06.04.00 Fisheries & 38 & 31 & 40 & 44 \\
\hline 07.00.00 History and Archeology & 34 & 33 & 39 & 33 \\
\hline 08.00.00 Economy & 32 & 31 & 33 & 32 \\
\hline 09.00.00 Philosophy & 35 & 34 & 43 & 35 \\
\hline 10.01.00 Literature & 33 & 37 & 36 & 32 \\
\hline 10.02.00 Linguistics & 33 & 34 & 33 & 31 \\
\hline 12.00.00 Law & 32 & 29 & 34 & 32 \\
\hline 13.00.00 Pedagogy & 38 & 40 & 44 & 39 \\
\hline 14.01.00 Clinical medicine & 33 & 32 & 33 & 35 \\
\hline 14.02.00 Preventative medicine & 35 & 30 & 37 & 40 \\
\hline 14.03.00 Biomedical Sciences & 33 & 32 & 34 & 37 \\
\hline 14.04.00 Pharmacy & 30 & 27 & 31 & 33 \\
\hline 17.00.00 Art history & 37 & 43 & 33 & 38 \\
\hline 19.00.00 Psychology & 34 & 32 & 36 & 35 \\
\hline 22.00.00 Sociology & 32 & 32 & 34 & 33 \\
\hline 23.00.00 Political science & 32 & 31 & 36 & 32 \\
\hline 24.00.00 Cultural studies & 36 & 39 & 34 & 36 \\
\hline 25.00.00 Earth sciences & 31 & 31 & 34 & 34 \\
\hline
\end{tabular}


The youngest candidates of science are employees of research institutes engaged in research in the field of the group "01.01.00 Mathematics". Researches from the group "13.00.00 Pedagogy" have the greatest age of thesis defense. Researches from the groups "09.00.00 Philosophy", "06.04.00 Fisheries", and "17.00.00 Art History" also have high age values.
Fig. 1 and 2 show the values of rotation coefficients for candidates and doctors of sciences in the context of groups of scientific specialties and sectors of the economy: universities, institutes of the Academy of Sciences, other research institutes, design bureaus, and other organizations.

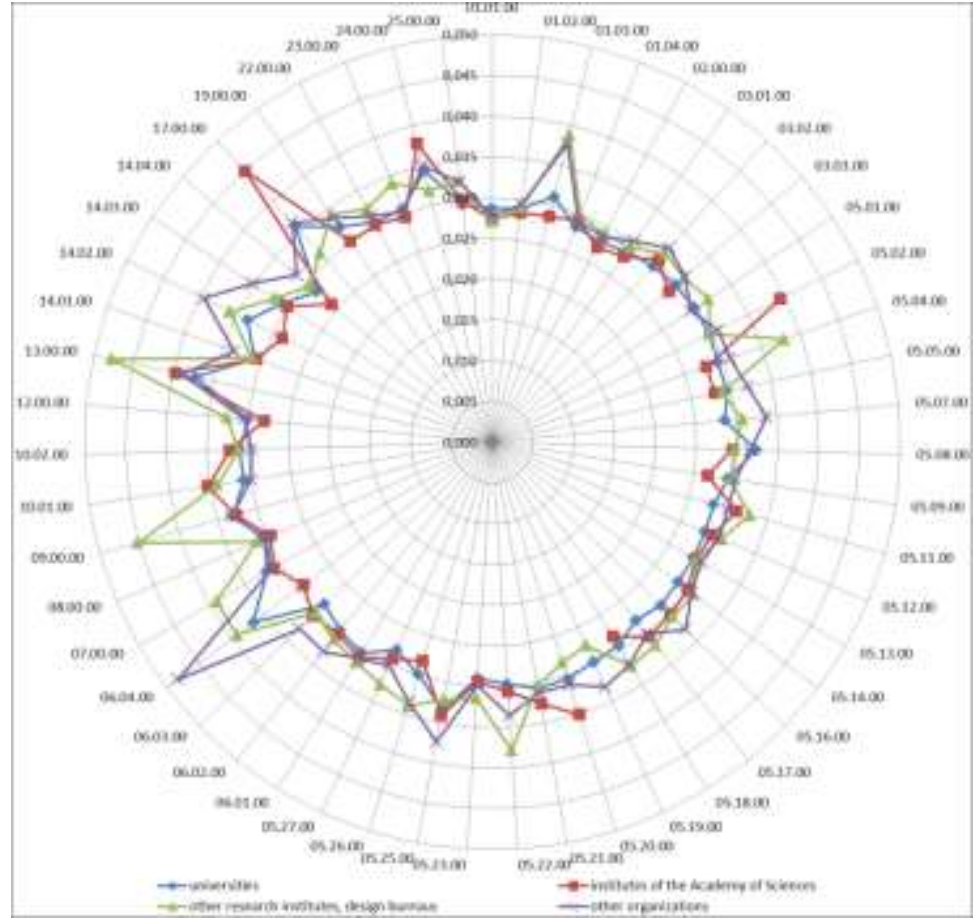

Fig. 1. Values of the rotation coefficient for candidates of science

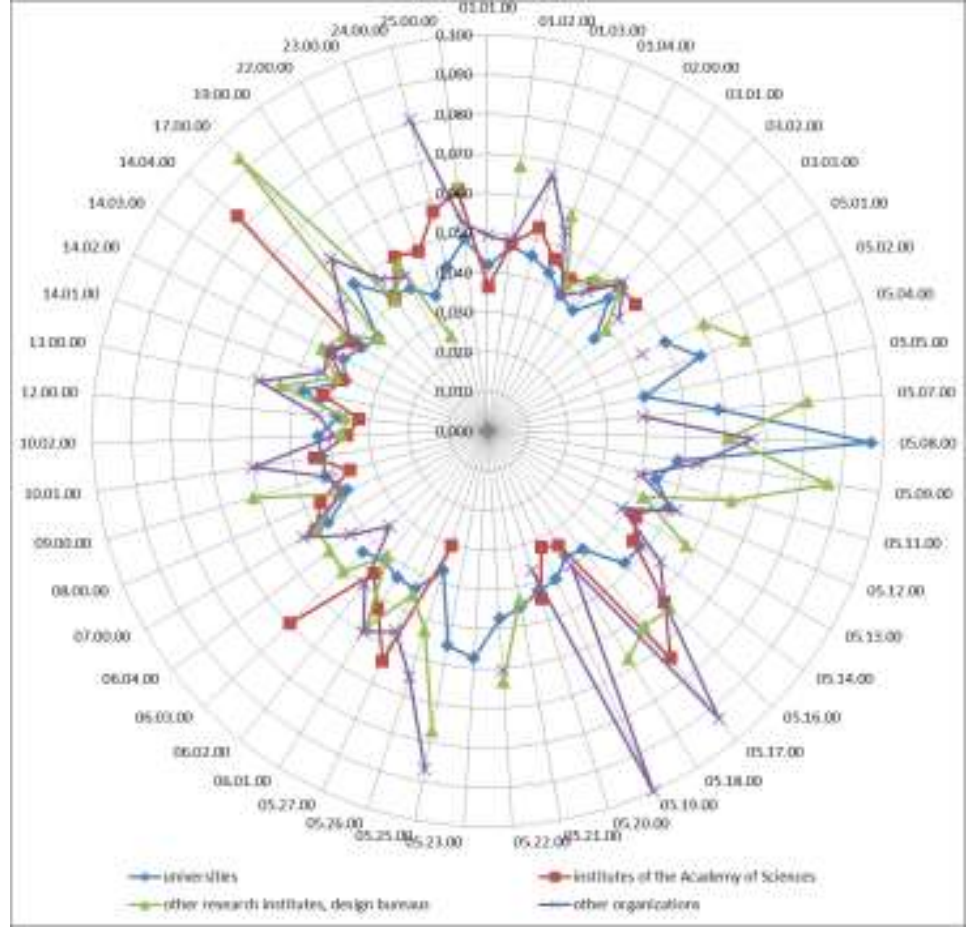

Fig. 2. The values of the rotation coefficient for doctors of science 
With an equal age of graduation, the rotation coefficient is higher for those scientific specialties where the age of defense is higher. For doctors of sciences employed in universities, a high value of rotation coefficient is observed for scientific specialties from the group 05.08.00 Shipbuilding, for the Academy of Sciences - 05.17.00 Chemical Technology.

For applicants for a medical degree working in medical institutions, the defense of candidate thesis takes place at a more mature age (Table 3).

TABLE III. AVERAGE AGE OF DEFENSE OF A THESIS IN MEDICAL SPECIALTIES

\begin{tabular}{|l|l|l|l|}
\hline \multicolumn{1}{|c|}{ Specialties } & $\begin{array}{c}\text { Medical } \\
\text { institution }\end{array}$ & University & $\begin{array}{c}\text { Academy } \\
\text { of } \\
\text { Sciences }\end{array}$ \\
\hline 14.01.00 Clinical medicine & 35 & 32 & 32 \\
\hline 14.02.00 Preventative medicine & 41 & 35 & 30 \\
\hline 14.03.00 Biomedical Sciences & 37 & 33 & 32 \\
\hline
\end{tabular}

As a result, the rotation coefficient for these senior scientific staff will be higher and will be equal to: $0.034,0.042$ and 0.036 , respectively.

\section{CONCLUSION}

To predict the needs of the economy for senior scientific staff, it is necessary to conduct quantitative assessments of the annual natural-age retirement of candidates and doctors of sciences, taking into account the specifics of scientific research and their place of work. The article presents quantitative calculations of these indicators for two types of models in the context of groups of scientific specialties and sectors of the economy.

\section{REFERENCES}

[1] Cyranoski D., Gilbert N., Ledford H., Nayar A., Yahia M. The world is producing more PhDs than ever before. Is it time to stop? Nature. 2011. 472:276-279. DOI: 10.1038/472276a

[2] 2017 Career Tracking Survey of Doctorate Holders. Project Report.

[3] Gohberg L.M., Ditkovskij K.A., D'yachenko E.L. and other. Indikatory nauki: 2019: statisticheskij sbornik. [Science Indicators: 2019: Statistical Digest]. Moscow. Publ. House of National Research University Higher School of Economics. 2019. 328 p. (in Russian).

[4] Bondarenko N.V., Gohberg L.M., Kovaleva N.V. and other. Indikatory obrazovaniya: 2018: statisticheskij sbornik [Education Indicators: 2018: Statistical Digest]. Moscow. Publ. House of National Research University Higher School of Economics. 2018. 400 p. (in Russian).

[5] Gurtov V.A., Shchegoleva L.V. Forecasting the Economic Need for Personnel with Higher Scientific Qualifications. Studies on Russian Economic Development. 2018. Vol. 29. No. 4. Pp. 415-422. 